\title{
Palatability and Animal Preferences of Plants in Small and Fragmented Land Holdings: The Case of Wolayta Zone, Southern Ethiopia
}

\author{
Tibebu Kochare ${ }^{1 *}$, Berhan Tamir ${ }^{2}$ and Yisehak Kechero ${ }^{3}$ \\ ${ }^{1}$ Department of Animal Sciences, Samara University, Ethiopia \\ ${ }^{2}$ Addis Ababa University, Faculty of Veterinary Medicine and Animal Production Studies, Debrezeit, 34, Ethiopia \\ ${ }^{3}$ Arbaminch University, College of Agricultural Sciences, 21, Arbaminch, Ethiopia
}

Submission: December 09, 2017; Published: March 12, 2018

"Corresponding author: Tibebu Kochare, Department of Animal Sciences, Samara University, Samara, 132, Ethiopia, Email: tibbeecoach49@gmail.com

\begin{abstract}
Livestock production in the Wolayta zone is at risk due to recurrent drought, population growth and very small and fragmented average land holdings. Palatable plants become more susceptible to grazing and trampling under low, erratic and undependable rainfall, short growing season and eroded exposed steep soils. Current study was carried out to assess differential palatability of plants and preferences of plant species and parts by grazing animals in Wolayta zone, southern Ethiopia. The result of this study showed that Wolayta zone is highly populated area with average household size 6.8, but very small and fragmented land holdings ( $1.5 \pm 0.081$ ha) per household. A total of 145 palatable plant species were identified in the zone, from which, $48(33.1 \%)$ were trees, 27 (18.6\%) were shrubs and the remaining $70(48.3 \%)$ were herbs. Of the 145 recorded species, $82(56.6 \%)$ were highly palatable, $25(17.2 \%)$ were mostly palatable, $24(16.6 \%)$ were less palatable, and $14(9.6)$ were rarely palatable. Goats preferred the most plants (139 species, 95.8\%), cattle (121 species, 83.4\%), sheep (106 species, 73.1\%) and donkeys (67 species, $46.2 \%$ ). Goats preferred herbs ( 66 species, $47.5 \%$ ), trees ( 46 species, $33.1 \%$ ) and shrubs ( 27 species, $19.4 \%$ ). Goat preferred herbs ( 67 species, $54.0 \%$ ), trees (34 species, 28.1\%) and shrubs (20 species, 16.5\%). Sheep preferred herbs (64 species, 60.4\%), trees (24 species, $22.6 \%)$ and shrubs (18 species, $17.0 \%$ ). The donkeys also preferred herbs (59 species, $88.0 \%$ ), trees ( 4 species, $6.0 \%)$ and shrubs (4 species, $6.0 \%)$. Most of the animals preferred the leaf part of plants ( 78 species, $53.8 \%$ ), shoots/whole parts ( 53 species, $36.5 \%$ ), fruits and/or flowers (53 species, $36.5 \%$ ), twigs ( 41 species, $28.3 \%$ ) and roots ( 6 species, $4.1 \%$ ). Root crops produced in the area like Manihot esculenta, Ensete ventricosum, Colocasia esculenta and Dioscoreaalatawere consumed by humans but animal parts not used byhumans like leaves, peels, flowers and twigs.
\end{abstract}

Keywords: Differential palatability; Preference; Plant species; Plant parts; Grazing animals; Wolayta

\section{Introduction}

Livestock production in the Wolayta zone includes cattle (oxen, milking cows and young stock), goat and sheep, equines (horses and donkeys), poultry (local and improved breeds). Animals are fed in open grazing, stall feeding and tethered (small area of open grazing left in front of a house) [1]. However due to recurrent drought, population growth and very small land holdings, livestock production in the zone is at risk [24]. Palatable plants become more susceptible to grazing and trampling under low, erratic and undependable rainfall, short growing season and eroded exposed steep soils [5,6]. Many other studies also concluded that over grazing reduces palatable cover and species diversity [7-10].

Palatability refers to the delight with which plants or its parts or feed is consumed as determined by the stimulation of the sensory impulses of grazing animal [11]. While preference is the selection of a plant species by the animal as a feed [12]. Palatability is affected through different animal factors such as differential preference for forage species, period, and phase of pregnancy, general health and hunger of animal. Palatability is also affected through different plant factors such as seasonal availability of plant, degree of maturity, growth stage, phenology, morphological and chemical nature [13].

Different animals prefer different plant species and parts [12]. No study has been conducted in Wolayta zone to identify palatable plant species and animal preference of plant species and parts except some few researches on characterization of some multipurpose trees used for animal feeding, types and availability of feeds $[3,14]$, feed resource situation $[5,15]$ and improved feed utilization [2].

Considering the need of information and significance of the study area, the current effort was carried out to assess i) differential palatability of plants and ii) preferences of plant species and parts by grazing animals in Wolayta zone, southern Ethiopia. 


\section{Materials and Methods}

\section{Location}

Wolayta zone is located $390 \mathrm{~km}$ southwest of Addis Ababa following the tarmac road that passes through Shashamane to Arbaminch. Alternatively, it is located $330 \mathrm{~km}$ southwest of Addis Ababa following the tarmac road that passes through ButajiraHalaba to Arbaminch. The zone has a total area of $4,541 \mathrm{~km} 2$ and is composed of 12 woredas and 3 registered towns. The population of Wolayta zone is about $1,527,908$ million of which $49.3 \%$ are male and $51.7 \%$ are female [16]. Out of these, $11.7 \%$ live in towns and the rest $88.3 \%$ live in rural areas. The annual population growth rate of the zone is $2.3 \%$. It is one of the most densely populated areas in the country with an average of 290 people per $\mathrm{km} 2$. The area is divided into three ecological zones: Kolla (lowland $<1500 \mathrm{~m}$ ), Woina-Dega (mid-altitude 1500-2300m) and Dega (highland $>2300 \mathrm{~m}$ ). Most of the area lies within the mid altitude zone [1,3]. The Zone is located between 6.40- 7.10 $\mathrm{N}$ and 37.40-38.20E, latitude and longitude respectively (Figure 1).

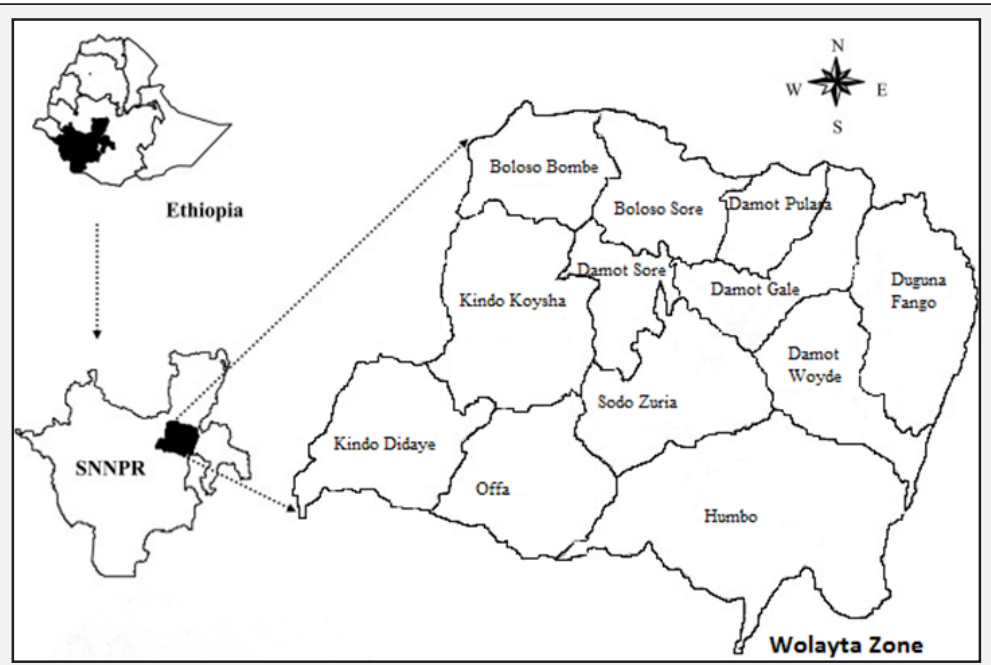

Figure 1: Map of Wolayta zone.

Wolayta zone is approximately 2000 meters above sea level and its altitude ranges from 700-2900 meters. Rainfall occurs in two distinct rainy seasons, 'kremt' rains (also called the 'big rains') occurring in summer (roughly June, July and August) and 'belg' rains (also called the 'small rains') occurring in spring (roughly the mid-February to mid-May period). Kremt is the main production season, but the occurrence of rain during the belg season is equally important as it has implications on the food security of the households. The average amount of rainfall is about $1000 \mathrm{~mm}$ (lower in the lowlands and higher in the highlands). Mean monthly temperature vary from $26^{\circ} \mathrm{C}$ in January to $11^{\circ} \mathrm{C}$ in August [17]. Soils (Eutric Nitisoils associated with Humic Nitisoils, which are dark reddish brown with deep profiles and vertisoils, are the most prevalent types in Wolayta zone $[3,20,21]$.

Primary occupation of the zone is farming. Mixed croplivestock production predominates, but there were some pastoralists in the lowlands [3]. Livestock production in Wolayta zone included cattle (oxen, milking cows and young stock), goats and sheep, equines (horses and donkeys), poultry (local and improved breeds). Cattle that are kept for milk production, draught power, cash and manure, dominate livestock numerically. In addition, farmers own cattle as wealth indicator. Animals are fed in open grazing, stall feeding and tethered (small area of open grazing left in front of a house). Generally, the climatic condition is conducive to livestock production [1].

\section{Data collection}

Data were achieved through interviewing 176 randomly selected respondents. A special questionnaire (to record palatable plants, their local name and parts consumed by the animals) was distributed to elders and herders, who are the authentic users and have plenty information about the plants and their palatability and preferences by animals. In addition 50 households were selected purposively based on their educational background for monitoring differential palatability of plants.

Identification of palatable plant species: To identify palatable plant species, all the plant species available on the area were recorded on the basis of different research papers, published and unpublished books, and the information from local communities who are familiar with the plant species. The plants local names were matched to their scientific names.

Differential Palatability: Differential palatability of plants was recorded by daily observing the grazing animals for one year (from November 2016 to October, 2017). The special questionnaire prepared for this purpose were administered to households selected for monitoring palatability of plants. The field observations were further related with the information/ knowledge gathered from local herders/elders and questionnaire findings. Plants were then classified into following palatability classes [12]. 
a. Non palatable (NP): Not grazed by animals at any stage; possibly toxic or harmful.

b. Highly palatable (HP): Species, which were preferred the most by livestock.

c. Mostly palatable (MP): Species with average preference by the livestock.

d. Less palatable (LP): Species with less preference.

e. Rarely palatable (RP): Species rarely grazed under compulsion when no other forage was available.

Differential palatability of plant parts and animal preference: The palatable species were further classified on the basis of animal preferences (all animal species available) and parts consumed (leaves, whole plant, fruits, twigs and roots).

\section{Data management and analysis}

Survey data were coded and entered into Microsoft office excel sheet every day after administering questionnaire to prevent loss of data. The collected data were analyzed using simple descriptive statistics, summarized and presented in figures, percentages and means using R software version 3.3.3.

\section{Results and Discussion}

\section{Household characteristics}

Wolayta zone is a densely populated and intensively cultivated mid-altitude area of Ethiopia. According to this survey, average household size of the study site was 6.8 which was comparable with the result of 5.1 [22], 6.56 [23], and 6.74 [24] in the area. From the total sampled households heads, $22.7 \%$ were illiterate, $47.7 \%$ completed primary school, $23.9 \%$ completed secondary school and 5.7\%. The average land holding of the study area was $1.5 \pm 0.081 \mathrm{ha}$. Some authors found smaller land holdings 0.62 ha [18] in the area than current study, but there were also comparable findings by other authors 1.41 ha of [17]. Farmers kept a mix of cattle, sheep, goats, donkeys and chicken. Average livestock ownership in terms of Tropical Livestock Unit (TLU) was 3.42, which is similar with the findings of [18].

\section{Differential palatability of plants}

This study showed that in Wolayta zone, 145 plants were identified as palatable by all livestock species. Among the palatable species, $48(33.1 \%)$ were trees, $27(18.6 \%)$ were shrubs and the remaining $70(48.3 \%)$ were herbs. Of the 145 recorded species, $82(56.6 \%)$ were highly palatable, 25 (17.2\%) were mostly palatable, 24(16.6\%) were less palatable, and 14 (9.6) were rarely palatable (Figure 2).Highest percentages of highly palatable plants were recorded in this study compared to the findings of [13] (16.66 \%) and [19] (19.88\%). Most of the less (15 species, $54.1 \%$ ) and rarely (8 species, $57.1 \%$ ) palatable species were from trees. Some of them include Vernonia sp., Rhus glutinosa, Nuxia congesta and Schrebera alata from less palatable and Eucalyptus globulus, Combretum molle, Rhus natalensis and Rytigynia neglecta from rarely palatable species. These species were less palatable and mostly rejected by the livestock, which have resulted in dominating large areas as overgrazing has decreased the number of palatable species which agreed with the findings of $[7,8,25]$ who concluded that over grazing reduces palatable cover and species diversity.

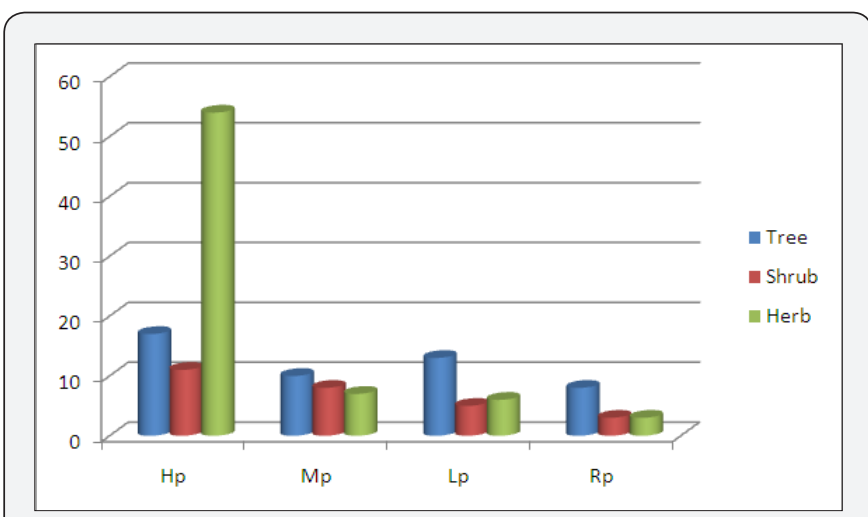

Figure 2: Differential palatability of plants.

\section{Preferences of plants by grazing animals}

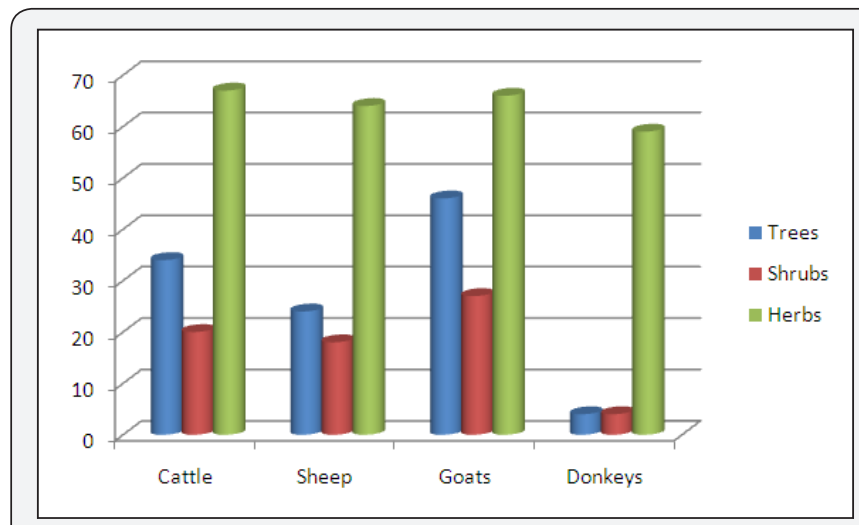

Figure 3 : Preference of plant species by grazing animals.

The preference of cattle, sheep, goat and donkeys for plant species is presented (Figure 3). Goat preferred the most plants (139 species, 95.8\%), cattle (121 species, 83.4\%), sheep (106 species, $73.1 \%$ ) and donkeys (67 species, $46.2 \%$ ). Goat preferred herbs ( 66 species, $47.5 \%$ ), trees (46 species, $33.1 \%$ ) and shrubs (27 species, 19.4\%). Cattle preferred herbs (67 species, $54.0 \%$ ), trees (34 species, 28.1\%) and shrubs (20 species, 16.5\%). Sheep preferred herbs (64 species, $60.4 \%$ ), trees (24 species, $22.6 \%$ ) and shrubs (18 species, $17.0 \%$ ). The donkeys also preferred herbs (59 species, $88.0 \%$ ), trees (4 species, $6.0 \%$ ) and shrubs ( 4 species, $6.0 \%$ ).Animal species differ markedly in their food habits; with each species showing innate preferences for certain plants, parts of plants, or plants in particular growth stages. Grazing animals exhibit variation in preference from one location to another $[26,27]$ from one season to another $[28,29]$ over a period of few days [29] within the same day [30] and among individuals $[28,30]$. The study area is densely populated and land ownership is small which has resulted in over use of existing palatable species and in shifting of animals' food habit 
to some non-palatable or less palatable species. Most plants are poisonous only when eaten in large amounts at particular stage but might provide nutritive forage when consumed in small amounts or mixed with other forage [12].

\section{Differential palatability of plant parts}

It was observed that, most of the animals preferred the leaf part of plants (78 species, $53.8 \%$ ), shoots/whole plants (53 species, $36.5 \%$ ), fruits and/or flowers (53 species, $36.5 \%$ ), twigs ( 41 species, $28.3 \%$ ) and roots (6 species, $4.1 \%$ ) (Figure 4). Root crops produced in the area like Manihote sculenta, Ensete ventricosum, Colocasia esculenta and Dioscorea alata were consumed by humans but animals fed parts not used by humans like leaves, peels, flowers and twigs. The rejection or preference of species/parts of plants by an animal is closely related to the availability of the plant in the pasture. It is possible that a plant or part of plant was rejected under certain conditions but preferred under other circumstances. Annual forbs/grasses besides their importance in nutritional contributions also reduced grazing pressure on palatable perennial species as animals shifted from browsing on trees and shrubs to grasses and herbs when they began to grow starting from March, when short rainy season started. It was found out that low quality or non-palatable plants/ plant parts replaced/dominated good quality forage plants under poor management/drier periods when no other materials were available to graze/browse. Therefore, the findings of this study agreed with others like [19] who stated that most of the forage species are present in March to April and fodder availability is high in this time and [31] stated that in the absence of annuals, the shrubs provide fresh fodder for animals.

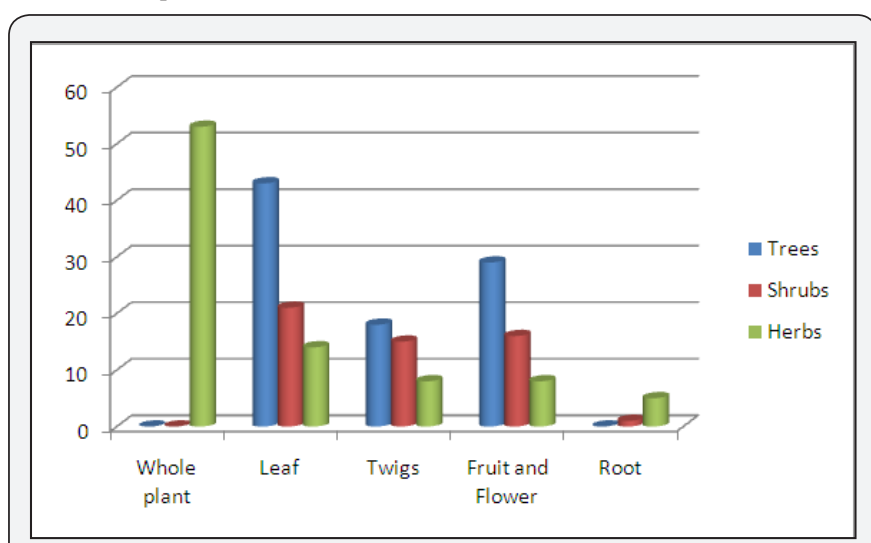

Figure 4: Differential palatability of plant parts.

\section{Conclusion}

The result of this study showed that Wolayta zone is highly populated area with average household size 6.8., but very small and fragmented land holdings $(1.5 \pm 0.081 \mathrm{ha})$ per household. About 145 palatable species were identified in the zone, among which 48 (33.1\%) were trees, 27 (18.6\%) were shrubs and the remaining $70(48.3 \%)$ were herbs. Of the 145 recorded species, 82 (56.6\%) were highly palatable, 25 (17.2\%) were mostly palatable, 24 (16.6\%) were less palatable, and 14 (9.6) were rarely palatable. Goat preferred the most plants (139 species, 95.8\%), cattle (121 species, 83.4\%), sheep (106 species, $73.1 \%$ ) and donkeys (67 species, $46.2 \%$ ). Goat preferred herbs (66 species, $47.5 \%$ ), trees (46 species, $33.1 \%$ ) and shrubs (27 species, 19.4\%). Cattle preferred herbs (67 species, 54.0\%), trees (34 species, $28.1 \%$ ) and shrubs (20 species, 16.5\%). Sheep preferred herbs (64 species, $60.4 \%$ ), trees (24 species, $22.6 \%$ ) and shrubs (18 species, $17.0 \%$ ). The donkeys also preferred herbs (59 species, $88.0 \%$ ), trees ( 4 species, $6.0 \%$ ) and shrubs (4 species, $6.0 \%$ ).Most of the animals preferred the leaf part of plants (78 species, $53.8 \%$ ), shoots/whole parts (53 species, 36.5 $\%$ ), fruits and/or flowers (53 species, $36.5 \%$ ), twigs (41 species, $28.3 \%$ ) and roots ( 6 species, $4.1 \%$ ). Root crops produced in the area were consumed by humans but animals consumed parts not used by humans like leaves, peels, flowers and twigs.The rejection or preference of species/parts of plants by an animal is closely related to the availability of the plant in the pasture.

\section{References}

1. Berhanu Kuma, (2012) A Market Access and Value Chain Analysis of Dairy Industry in Ethiopia: The Case of Wolayta zone. Haramaya University, Ethiopia.

2. Zereu G and Lijalem T (2016) Status of improved forage production, utilization and constraints for adoption in Wolaita Zone, Southern Ethiopia. Livestock Research for Rural Development 28(5).

3. Pound B, Jonfa E (2006) Cattle in Southern Ethiopia: Participatory studies in Wolaita and Konsoworedas FARM-AFRICA Working Papers No. 3.

4. Asrat A, Feleke A, Ermias B (2016) Characterization of Dairy Cattle Production Systems in and around WolaitaSodo Town, Southern Ethiopia. Scholarly Journal of Agricultural Science 6(3): 62-70.

5. Jimma A, Tessema F, Gemiyo D, Bassa Z (2016) Assessment of Available Feed Resources, Feed Management and Utilization Systems in SNNPRS of Ethiopia. J Fisheries Livest Prod 4: 183.

6. Adimasu Y (2008) Assessment of livestock feed resource utilization in AlabaWoreda, Southern Ethiopia. Masterss Thesis, Haramaya University, Harar, Ethiopia.

7. Hussain F, Durrani Mj (2007) Forage productivity of arid temperate Harboi rangeland, Kalat, Pakistan. Pak J. Bot 39(5):1455-1470.

8. Hussain F, Durrani Mj (2008) Mineral composition of some range grasses and shrubs from Harboi rangeland Kalat, Pakistan. Pak. J. Bot 40(6): 2513-2523

9. Hussain F, SR Chaghtai (1984) The effect of overgrazing on the development of herbaceous vegetation in Zangilora, Quetta, Balochistan, Pakistan. Pakistan Area Study Journal 91: 29-38.

10. Batanouny K.H (1996) Biodiversity in the rangelands of the Arab countries. In: Proc. Rangelands in a sustainable biosphere. NE West $\left(5^{\text {th }}\right.$ edn), International Congress, Salt Lake City Utah, p. 39-40.

11. Heath Me, Barnes Rf, Metcalfe Ds (1985) Forages: The Science of Grassland Agriculture. Iowa State University, Aimes.

12. Hussain F, Durrani Mj (2009) Seasonal availability, palatability and animal Preferences of forage plants in Harboi arid Range land, Kalat, Pakistan. Pak J Bot 41(2): 539-554.

13. Muhammad ShoaibAmjad, Muhammad Arshad, Sammer Fatima, Nosheen Mumtaz 2014.

14. Adugna T (1990) Animal production and feed resource constraints in Wolayita Sodo and the supplementary value of Desmodiumintortum, 
Stylosanthes guianens is and Macrotyloma axillare when fed to growing sheep feeding on a basal diet of maize stover. Master's thesis Agricultural University of Norway, Norway.

15. Adugna T (2007) Feed Resources for Producing Export Quality Meat and Livestock in Ethiopia: Examples from Selected Woredas in Oromia and SNNP Regional States. Ethiopia Sanitary and Phytosanitary Standards and Livestock and Meat Marketing (SPS-LMM) Program, Addis Ababa, Ethiopia, p. 77.

16. Central Statistical Agency (CSA) (2007) Summary and Statistical Report of the 2007. Population and Housing Census Results. Federal Democratic Republic of Ethiopia: Population Census Commission.

17. Ayele Tesema, N. Shanmugaratnam (2008) Fighting a losing battle? Livelihood adaptation and diversification in Wolaita Ethiopia, Noragric Norwegian University of Life Sciences, Norway.

18. Gian Luca Bagnara (2017) Agricultural production and market of Wolaita rural area (Ethiopia). Technical Report.

19. Musharaf Khan, Farrukh Hussain (2012) Palatability and animal preferences of plants in Tehsil Takhte-Nasrati, District Karak, Pakistan. African Journal of Agricultural Research 7(44): 5858-5872.

20. Tesfaye B (2003) Understanding farmers. Wageningen University and Research Center, Wageningen.

21. Takele Geta Gina, Lisanework Nigatu, Getachew Animut (2014) Biodiversity of Indigenous Multipurpose Fodder Trees of Wolayta Zone, Southern Ethiopia. 4 (5).

22. Tekle, Birhanu (2015) Determinants of Rural Farm Household Food Security in Boloso Sore District of Wolaita Zone in Ethiopia. Asian Journal of Agricultural Extension, Economics \& Sociology 5(2): 57-68.
23. Yishak Gecho (2017) Rural Farm Households' Income Diversification: The Case of Wolaita Zone, Southern Ethiopia. Social Sciences 6(2): 4556.

24. Tsedeke K, G Endrias (2011) Agro-ecologic mapping of livestock system in smallholder crop-livestock mixed farming of Wolaita and Dawuro districts, Southern Ethiopia. Livestock arch for rural development 23(3).

25. Shaheen H, Qureshi R, Akram A, Gulfraz M (2014) Inventory of medicinal flora from Thal desert, Punjab, Pakistan. Afr J Tradit. Complement Altern Med 11(3):282-290

26. Dasmann Wp (1949) Deer-livestock forage studies on the interstate winter deer range in California. J. Range Mgmt pp.5206-5212.

27. Leach HR (1956) Food habits of the Great Basin deer herds of California. Calif. Fish and Game 42: 243-308.

28. Heady H F, T Torell (1959) Forage preferences exhibited by sheep with esophageal fistulas. J Range Mgmt 12: 28-34.

29. Nichol A. A (1938) Experimental feeding of deer. Ariz Aar Exn Sta T\&h Bull p. 39-75.

30. Van Dyne GM (1963) Forage intake and digestion by cattle and sheep on a common dry foothill annual range. Univ. of Calif, Davis.

31. Marqueus Roper JJ, Salvalaggio Apb (2004) Phenological patterns among plants life-form in a subtropical forest in Southern Brazil. J. Plant. Ecol 173(2): 203-312.

\begin{tabular}{|l|}
\hline \multicolumn{1}{|c|}{ Your next submission with Juniper Publishers } \\
will reach you the below assets \\
- Quality Editorial service \\
- Swift Peer Review \\
- Reprints availability \\
- E-prints Service \\
- Manuscript Podcast for convenient understanding \\
- Global attainment for your research \\
- Manuscript accessibility in different formats \\
( Pdf, E-pub, Full Text, Audio) \\
- Unceasing customer service \\
Track the below URL for one-step submission \\
https://juniperpublishers.com/online-submission.php \\
\hline
\end{tabular}

